\title{
What Facilitates the Delivery of Citizen-Centric E- Government Services in Developing Countries: Model Development and Validation Through Structural Equation Modeling
}

\author{
Yousef Elsheikh ${ }^{1}$ and Mohammad Azzeh ${ }^{2}$ \\ ${ }^{1}$ Department of Computer Science, Applied Science University, Amman, Jordan \\ ${ }^{2}$ Department of Software Engineering, Applied Science University, Amman, Jordan
}

\begin{abstract}
Yet, existing research on the delivery of citizen-centric e-government services in developing countries is still lacking explanatory power for the following reasons: 1) focus either on the supply-side of these services, or on the demand-side separately, thus there is no enough research on the integration between them, and 2) focus on the results of previous research, thus ignoring the development of theories fit the new context under investigation by understanding the relationship between the implementation of ICT and social structures in the same context. This study aims to fill these gaps by employing a holistic approach to enable in-depth understanding and gain valuable insights for success factors in the delivery of citizencentric e-government services from multiple perspectives, and in the real context of one of the Arab countries, namely Jordan. This would reduce the gap between strategies and government policies on the one hand, and the perceptions of citizens on the other hand about the determinants of the delivery of citizen-centric e-government services in developing countries, allowing a better understanding of citizens' needs and priorities that must be taken into account by those governments in order to ensure the success of those services on a large scale. This study is part of a two-phase research aims to propose an integrated model of success factors in the delivery of citizen centric e-government services and then validate it in the context of developing countries in general and Jordan in particular. The first phase, which is beyond the scope of this study, employs grounded theory method to develop a research model, as well as survey instruments necessary to validate it. The second phase, which is within the scope of this study, employs survey questionnaire method to validate the research model by using multivariate and structural equation modeling (SEM). The results show that factors such as the perception of ease of use as well as the perception of usefulness are no longer affect the delivery of citizen-centric e-government services in this particular context. The results also show that the perception of organizational loyalty through more involvement of citizens in the decision-making process of change, as well as awareness-raising campaigns for such e-services, is among the positive and significant factors that affect the delivery of citizen-centric $e$ government services in the same context. Perception of trust, quality and security in e-services, all of these have significance and positive impact on the delivery of such e-services in this particular context. Website design is also among the factors that have significance and a positive impact in the same context. Most importantly, the results show that the national e-readiness, including the macro political environment, legal and regulatory environment, socio-economic environment and infrastructure related to ICT, is among the factors that have significance, but did not reach to become positive in this particular context. However, the modern Arab culture stands out as among the factors that have significance, as well as a positive impact in this context. Finally, this study concludes by highlighting the theoretical and practical implications, limitations and future directions.
\end{abstract}

\section{KEYWORDS}

ICT, citizen-centric e-government services delivery, grounded theory, structural equation modeling, developing countries, Jordan. 


\section{INTRODUCTION}

E-government is not only the provision of public services over the Internet, but a radical change in societies, and this is what makes the delivery of e-government services raises a lot of controversy today. Most governments around the world have realised the importance of managing information and government services through the Internet. According to the UN E-Government Survey 2012: E-Government for the People; 190 out of 193 member states has some online presence, either through a national portal or the ministry's website. Despite this high potential, many researchers pointed that the delivery of citizen-centric e-government services is still a challenge to some governments around the world, both in developed and developing countries [1][2][3]. For example, [4] found that only $40 \%$ of Taiwanese pay their taxes electronically while the rest use paper based forms. [5] showed that only $21 \%$ of citizens are aware of e-government services and applications in Jordan. Another study showed that $23.6 \%$ of those surveyed were aware of e-government services and applications in the State of Kuwait [6]. However, the case of developed countries is not much better from developing countries in terms of the delivery of citizen-centric e-government services. [7] pointed out that the average use of Canadian citizens for e-government websites is $30 \%$, while the average use of Polish citizens is \%20 [8]. Also, [9] pointed out that $76 \%$ of the households of those surveyed were not aware of the government gateway in the UK; only $6 \%$ were registered for the government gateway. In the US, the case may be slightly better in terms of the utilization rate of e-government services. For example, 52\% of taxpayers in the US were using the Internet to pay their taxes in 2005. In 2007, this percentage rose to $60 \%$, which means that the increase was very slight [10]. The reason behind such low rates is the mistaken belief that the results of studies related to the delivery of citizen-centric egovernment services can be generalized as if they were in a global context. But it is not that easy because the needs of each country and contextual circumstances vary from country to country around the world. Thus, a global approach may not be effective in all contextual circumstances, but on the contrary may fail to deliver e-government services to beneficiaries. This study, therefore, fills this gap by identifying and empirically tests the success factors that affect the delivery of citizen-centric e-government services from multiple perspectives. Although this study focuses on the context of Jordan, the results can be generalized to other countries with similar circumstances.

\section{LITERATURE REVIEW}

In recent years, there has been increasing interest by researchers for developing theories and models to understand the factors that affect the delivery of citizen-centric e-government services in different contexts [2][3][6][11][12][13][14]. Currently, there is no model fits different egovernment contexts. Therefore, the study of such models and theories has become a necessity in spite of differences in research methodologies and contexts where applied. These theories and models are often subject to cultural considerations in developed countries like the US where formulated, which means that these models and theories do not fit the contexts of developing countries due to differences with developed countries in terms of societal, cultural and national infrastructural factors [15]. In the IS literature, there are three groups of theories and models to explain the IT innovation process as follows:

- Models, such as Diffusion of Innovation (DOI) and its derivatives are based on the perception of the characteristics of the system (technology) to influence human behaviour towards the delivery of IT [16].

- Models, such as Technology Acceptance Model (TAM) and its derivatives are based on the formation of intention (personal beliefs and attitudes) as a criterion of decision-making to influence human behaviour towards the delivery of IT [17][18].

- Models, such as Social cognitive Theory, Intrinsic and Extrinsic Motivation (IEM), and Theory of Interpersonal Behaviour (TIB), are based on the integration of the goal 
achievement as a criterion of decision-making. Also, the automatic factor (past behaviour), and the social factors (norms and social identity) of goal-directed behaviour, have an influence human behaviour towards the delivery of IT. In addition, motivation-oriented perspectives enhance the understanding of the basic mechanism underlying both the intrinsic (IM) and extrinsic motivation (EM) process [19].

Most of the existing research on the IT innovation and e-government are classified into two key sides: supply and demand-side. The supply-side includes factors related to the source of public services (government and its partners) at all levels local, state or national [20]. In practice, the supply-side includes factors that affect the government institutions to deliver information and egovernment services [5][21]. Among these factors highlight the IT infrastructure, financial resources, human resources and change management. While the demand-side includes factors related to the beneficiaries of public services, whether citizens, businesses or government employees [20]. In practice, the demand-side includes factors that affect the beneficiaries to utilize information and e-government services [2][6][13][14][22][23]. Among these factors highlight the trust, culture, perceptions, beliefs and experience. Few of these studies were designed to explore the factors that affect the delivery of citizen-centric e-government services by looking at multiple perspectives to ensure the success of such e-services on a large scale. These studies would support governments at various levels in the development of policies and procedures that meet the needs of stakeholders and their perceptions on e-government services, thus reducing the gap between the technology implemented by governments and that perceived by the citizens. For Arab countries, the number of studies on the factors that affect the delivery of citizen-centric e-government services from both the supply and demand-side is relatively few compared with studies conducted in developed countries, and even other Asian developing countries. [24], for example, explored factors that facilitate the delivery of e-government from both the supply and demand-side in the Sultanate of Oman. From the demand side, the results indicate that the factors that affect the delivery of e-government services can be summarised in the characteristics of citizens such as IT literacy, age, education and income. According to this study, young citizens, the educated and those with high income were more likely to adopt egovernment services. In addition, citizens with expertise in the use of computers and the Internet are more likely to utilize e-government. This study also addressed the major barriers facing the government of the Sultanate of Oman to move forward in the delivery of e-government services.

These barriers are summarised in the lack of experience in the use of IT, lack of awareness and knowledge of e-government services and lack of trust in government and IT alike. [25], using the UTAUT, explored the demand-side factors that affect the utilization of citizen-centric egovernment services in Kuwait. The results indicated that factors such as facilitating conditions, peer influence, performance expectancy, and effort expectancy, explain the behaviour of Kuwaiti citizens towards the utilization of such e-services. The study also pointed to other factors such as culture, trust, which were not included in this context, but in future studies because of their importance. Similarly, but in different context, [26] explored using the UTAUT the demand-side factors that affect the behavioural intention of individuals to utilize citizen-centric e-government services in Qatar. The results showed three influential factors, performance expectancy, social influence, and facilitating conditions. The study also pointed to other factors such as culture, which was not included in this context, but in future studies because of its importance. [27] discussed the factors affecting the citizens' intention to adopt and use citizen-centric egovernment services, particularly the challenges facing the IT transfer in the Kingdom of Saudi Arabia on a large scale. The results showed that among those factors, quality of service, diffusion of innovation, computer and information literacy, culture, lack of awareness, technical infrastructure, website design, and security, which affect the citizens to adopt e-government services in the same context. For the context of this study, several researchers [2][28][29][30] explored the factors that affect the delivery of citizen-centric e-government services, but without 
exploring the depth of this issue from multiple perspectives. In other words, Most of these studies were not based on theories reflect the context under investigation, but they tend to employ the results of previous research. Therefore, the weakness in existing methodologies to study the delivery of citizen-centric e-government services would undermine the understanding of the relationship between IT innovation and social structures surrounding it. For this reason, the importance of this study comes not only in the emphasis on the inadequacy of the models and theories mentioned above, but also broaden the base of our understanding to explore other factors that affect the success of the delivery of IT in general and citizen-centric e-government services in particular. This study to the best of my knowledge is the first of its kind in Jordan to identify and test empirically the factors that affect the delivery of citizen-centric e-government services from multiple perspectives.

\section{RESEARCH MODEL AND HYPOTHESES}

Fifteen factors and their instruments were obtained from a previous study of the researcher, using a variety of sources, such as individual interviews, focus groups, observations, and analysis of documents. In that study, grounded theory method was applied for data collection and analysis. However, these factors, which are summarized in Table 1, showed that success in the delivery of citizen-centric e-government services in the context of developing countries is not an easy task since it depends on a complex mix of factors, which are grouped into four main perspectives, namely the national, governmental, citizen and technological perspective. However, Figure 1 summarizes the results of applying grounded theory method by linking the dependent factor to the other fifteen independent factors of different levels to reach a preliminary formulation of the research model on the one hand, and the research hypotheses on the other hand.

Table 1. Success factors and their instrument items in the delivery of citizen-centric e-government services resulting from grounded theory study

\begin{tabular}{|c|c|c|c|}
\hline Perspective & Factor & Instrument item(s) & Description \\
\hline \multirow{4}{*}{ National } & $\begin{array}{lr}\text { Existing } & \text { macro } \\
\text { political } & \text { environment } \\
(\mathrm{MPE}) & \end{array}$ & $\begin{array}{ll}\begin{array}{l}\text { Political objectives, } \\
\text { regulations, }\end{array} & \text { Political } \\
\text { skepticism, Political } & \text { support, } \\
\text { Political resources, and Political } \\
\text { stability }\end{array}$ & $\begin{array}{l}\text { The external environment } \\
\text { that cannot be controlled } \\
\text { and mostly has an impact } \\
\text { on decision-making in the } \\
\text { country, particularly } \\
\text { national strategies and } \\
\text { policies, which means the } \\
\text { impact on services } \\
\text { provided to all segments of } \\
\text { community }\end{array}$ \\
\hline & $\begin{array}{l}\text { Existing socio cultural } \\
\text { environment (SCE) }\end{array}$ & $\begin{array}{l}\text { Corruption, Language, Social } \\
\text { contact, Openness, Family, } \\
\text { Awareness, Religion, Prestige, } \\
\text { Fear authority, Power distance, } \\
\text { Future orientation, } \\
\text { Unemployment, Training, } \\
\text { Research, and Gender roles }\end{array}$ & $\begin{array}{l}\text { The practices, beliefs and } \\
\text { traditions within a } \\
\text { community }\end{array}$ \\
\hline & $\begin{array}{l}\text { Existing } \\
\text { infrastructure } \\
\text { (ICTINF) }\end{array}$ & $\begin{array}{lr}\text { E-commerce } & \text { infrastructure, } \\
\text { Reliability, } & \text { Postal } \\
\text { infrastructure, } & \text { Accessibility, } \\
\text { Availability, Affordability, and } \\
\text { Maintenance }\end{array}$ & $\begin{array}{l}\text { The technical services and } \\
\text { facilities required to enable } \\
\text { and deliver e-government } \\
\text { services and applications }\end{array}$ \\
\hline & $\begin{array}{lr}\text { Existing } & \text { socio } \\
\text { economic } & \text { environment } \\
(\mathrm{SEE}) & \end{array}$ & $\begin{array}{l}\text { IT market uncertainty, } \\
\text { Demographics, and Banking } \\
\text { services }\end{array}$ & $\begin{array}{lcr}\text { The combination } & \text { of } \\
\text { external social } & \text { and } \\
\text { economic conditions } & \text { that } \\
\text { affect government } & \text { to } \\
\text { support and enable the }\end{array}$ \\
\hline
\end{tabular}


International Journal of Computer Science \& Information Technology (IJCSIT) Vol 6, No1, February 2014

\begin{tabular}{|c|c|c|c|}
\hline & & & $\begin{array}{l}\text { delivery of e-government } \\
\text { services and applications }\end{array}$ \\
\hline & $\begin{array}{l}\text { Existing legal and } \\
\text { regulatory } \\
\text { environment (LRE) }\end{array}$ & $\begin{array}{l}\text { Up-to-date, Efficiency, and } \\
\text { effectiveness }\end{array}$ & $\begin{array}{l}\text { The basic legislation and } \\
\text { laws that support and } \\
\text { enable the delivery of e- } \\
\text { government services and } \\
\text { applications } \\
\text { community }\end{array}$ \\
\hline \multirow{4}{*}{$\begin{array}{l}\text { Governmen } \\
\text { tal }\end{array}$} & $\begin{array}{l}\text { Perceived } \\
\text { organizational change } \\
\text { management } \\
(\mathrm{ORGCHG})\end{array}$ & $\begin{array}{l}\text { Resistance to change, Support } \\
\text { to change, Communication to } \\
\text { change, and Training to change }\end{array}$ & $\begin{array}{l}\text { The set of processes that } \\
\text { ensure change management } \\
\text { towards delivery of e- } \\
\text { government services and } \\
\text { applications in an } \\
\text { organized, controlled and } \\
\text { systematic manner }\end{array}$ \\
\hline & $\begin{array}{l}\text { Perceived } \\
\text { organizational } \\
\text { integration (ORGINT) }\end{array}$ & $\begin{array}{l}\text { Information } \\
\text { Compatibility, } \\
\text { Restructuring }\end{array}$ & $\begin{array}{l}\text { The practice of bringing } \\
\text { together all organizational } \\
\text { subsystems into one whole } \\
\text { system and keep order } \\
\text { those subsystems run } \\
\text { together }\end{array}$ \\
\hline & $\begin{array}{l}\text { Perceived } \\
\text { organizational loyalty } \\
\text { (ORGLOY) }\end{array}$ & $\begin{array}{l}\text { Citizen participation in decision } \\
\text { making, } \\
\text { campaigns, } \\
\text { Incentives/rewards }\end{array}$ & $\begin{array}{l}\text { The increase in the role of } \\
\text { the citizen to participate in } \\
\text { the process of change and } \\
\text { decision-making regarding } \\
\text { the delivery of e- } \\
\text { government services and } \\
\text { applications }\end{array}$ \\
\hline & $\begin{array}{l}\text { Perceived managerial } \\
\text { efficiency (ME) }\end{array}$ & $\begin{array}{ll}\text { IT vision, IT support, IT } \\
\text { training, IT partnership, IT } \\
\text { resources, IT advisory, and IT } \\
\text { review }\end{array}$ & $\begin{array}{l}\text { The degree to which senior } \\
\text { management can achieve } \\
\text { the goals of supporting and } \\
\text { enabling e-government } \\
\text { services and applications }\end{array}$ \\
\hline \multirow{3}{*}{ Citizen } & $\begin{array}{l}\text { Perceived intrinsic } \\
\text { characteristics of the } \\
\text { citizen towards IT } \\
\text { (CZINTCHAR) }\end{array}$ & $\begin{array}{l}\text { IT attitudes, IT knowledge, IT } \\
\text { experience, IT } \begin{array}{l}\text { confidence, } \\
\text { innovativeness, } \\
\text { and Risk taking }\end{array}\end{array}$ & $\begin{array}{l}\text { The differences between } \\
\text { citizens that affect their } \\
\text { attitudes toward various } \\
\text { events, including the } \\
\text { change towards the } \\
\text { delivery of e-government } \\
\text { services and applications }\end{array}$ \\
\hline & $\begin{array}{l}\text { Perceived trust in e- } \\
\text { government services } \\
\text { (EGOVTRST) }\end{array}$ & $\begin{array}{l}\text { Trust in government and Trust } \\
\text { in e-services }\end{array}$ & $\begin{array}{l}\text { The citizen's belief or } \\
\text { expectation that the } \\
\text { government and IT will } \\
\text { provide a particular service } \\
\text { to the citizen in the absence } \\
\text { of citizen control on the } \\
\text { performance of both of } \\
\text { them. This includes citizen } \\
\text { trust in the performance of } \\
\text { both IT and government. }\end{array}$ \\
\hline & $\begin{array}{l}\text { Perceived aspects of e- } \\
\text { government services } \\
\text { usage (CZUSGASP) }\end{array}$ & $\begin{array}{l}\text { Ease of use, Self efficacy, } \\
\text { Usefulness, Peer influence, } \\
\text { Media influence, and } \\
\text { Commitment }\end{array}$ & $\begin{array}{l}\text { The cognitive and } \\
\text { perceptual aspects of the } \\
\text { citizens on the delivery of } \\
\text { e-government services and } \\
\text { applications }\end{array}$ \\
\hline
\end{tabular}




\begin{tabular}{|c|c|c|c|}
\hline \multirow[t]{3}{*}{$\begin{array}{l}\text { Technologi } \\
\text { cal }\end{array}$} & $\begin{array}{l}\text { Perceived quality of e- } \\
\text { services } \\
\text { (EGOVQLTY) }\end{array}$ & $\begin{array}{l}\text { Interactivity, Accessibility, } \\
\text { Competitiveness, Well-defined, } \\
\text { Availability, Cost-time } \\
\text { effectiveness, Responsiveness, } \\
\text { Traceability, Online-support, } \\
\text { Citizen-focused, Right the first } \\
\text { time, and Well-structured }\end{array}$ & $\begin{array}{l}\text { The extent to which a } \\
\text { website facilitates the } \\
\text { delivery of public services } \\
\text { efficiently and effectively, } \\
\text { including information, } \\
\text { communication and } \\
\text { interaction, contracting, } \\
\text { and transactions }\end{array}$ \\
\hline & $\begin{array}{l}\text { Perceived online safety } \\
\text { and } \quad \text { security } \\
(\text { ONSAFSEC) }\end{array}$ & $\begin{array}{l}\text { Security training, Risk } \\
\text { management, } \\
\begin{array}{ll}\text { privacy, and } & \text { Information } \\
\text { security }\end{array}\end{array}$ & $\begin{array}{l}\text { The protection of online } \\
\text { information and } \\
\text { transactions against } \\
\text { unauthorised access or } \\
\text { alteration of information, } \\
\text { both in storage and } \\
\text { processing, or transit, and } \\
\text { even against denial of } \\
\text { service caused by those } \\
\text { users who are authorised to } \\
\text { do so }\end{array}$ \\
\hline & $\begin{array}{lr}\begin{array}{l}\text { Perceived } \\
\text { design }\end{array} & \text { website } \\
(\text { WEBDSGN }) & \end{array}$ & $\begin{array}{l}\text { Multimodality, Personalization, } \\
\text { Updated regularly, Ease of } \\
\text { navigation, Sufficient } \\
\text { information, Ease of } \\
\text { remembering, Relevant } \\
\text { information, Free of errors, } \\
\text { Clear information, Website } \\
\text { map, and Contact }\end{array}$ & $\begin{array}{l}\text { The process of designing } \\
\text { and managing e- } \\
\text { government websites to } \\
\text { facilitate the delivery of } \\
\text { public services efficiently } \\
\text { and effectively, including } \\
\text { information and } \\
\text { communication, interaction } \\
\text { and contracting, and } \\
\text { transactions. }\end{array}$ \\
\hline
\end{tabular}

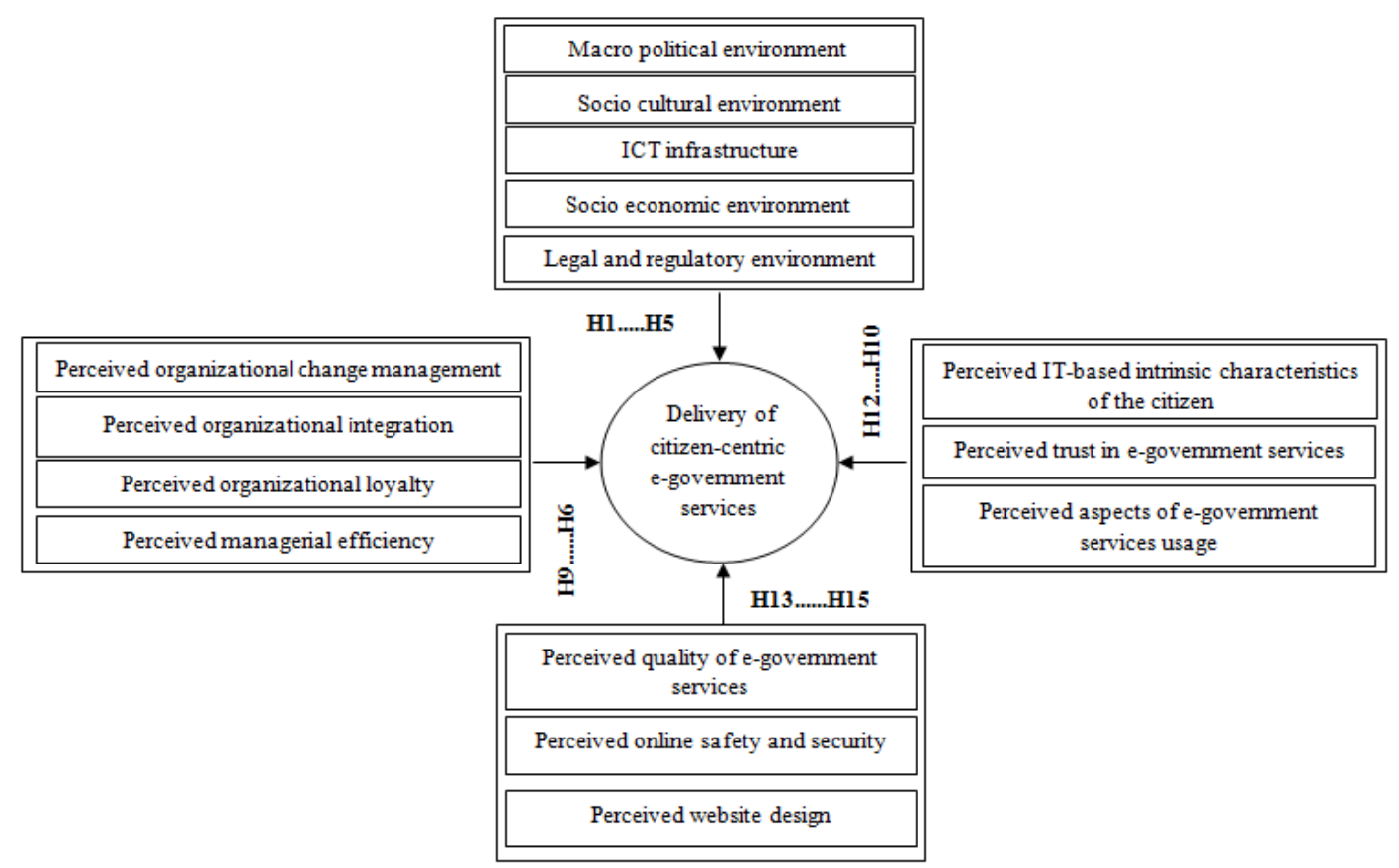

Figure 1. Research model and hypotheses 
Based on the research model in Figure 1, the following causal hypotheses are formulated in this study.

H1: There is a direct and positive relationship between existing macro political environment and the delivery of citizen-centric e-government services.

H2: There is a direct and positive relationship between existing socio cultural environment and the delivery of citizen-centric e-government services.

H3: There is a direct and positive relationship between existing ICT infrastructure and the delivery of citizen-centric e-government services.

H4: There is a direct and positive relationship between existing socio economic environment and the delivery of citizen-centric e-government services.

H5: There is a direct and positive relationship between existing legal and regulatory environment and the delivery of citizen-centric e-government services.

H6: There is a direct and positive relationship between perceived organizational change management and the delivery of citizen-centric e-government services.

H7: There is a direct and positive relationship between perceived organizational integration and the delivery of citizen-centric e-government services.

H8: There is a direct and positive relationship between perceived organizational loyalty and the delivery of citizen-centric e-government services.

H9: There is a direct and positive relationship between perceived managerial efficiency and the delivery of citizen-centric e-government services and applications.

H10: There is a direct and positive relationship between perceived intrinsic characteristics of the citizen towards IT and the delivery of citizen-centric e-government services.

H11: There is a direct and positive relationship between perceived trust in both government as well as IT and the delivery of citizen-centric e-government services.

H12: There is a direct and positive relationship between perceived aspects of the citizen towards IT usage and the delivery of citizen-centric e-government services.

H13: There is a direct and positive relationship between perceived quality of e-services and the delivery of citizen-centric e-government services.

H14: There is a direct and positive relationship between perceived online safety and security and the delivery of citizen-centric e-government services.

H15: There is a direct and positive relationship between perceived website design issues and the delivery of citizen-centric e-government services.

\section{RESEARCH METHODOLOGY}

In this study, one dependent factor and fifteen independent factors were tested using a two-step approach to estimate the research model [31], namely SEM. In simple terms, SEM involves the estimation of two models: a measurement model and a path model. This provides a better way to examine the theoretical models empirically [32].

\subsection{Research Instrument}

Of the research instruments that were developed from a previous study of the researcher, a further attempt of refinement was made to refine the structure of each factor using confirmatory factor analysis (CFA), the result is shown in Table 1. This provides a better understanding of what items truly measure the factors identified in the research model in Figure 1. This is usually done by evaluating the goodness-of-fit measures [33]. In this study, the measurement model fit was good and falls within acceptable limits, as shown in Table 2. 
Table 2. Overall goodness-of-fit measures for measurement model (all factors with their respective instrument items)

\begin{tabular}{|l|c|c|c|c|c|c|c|}
\hline \multicolumn{1}{|c|}{ Model } & RMSEA & CMIN/DF & GFI & AGFI & CFI & TLI & IFI \\
\hline Default model & 0.072 & 3.698 & 0.903 & 0.873 & 0.911 & 0.901 & 0.910 \\
\hline $\begin{array}{l}\text { Acceptable } \\
\text { limits }\end{array}$ & $<=0.08$ & $>1 \&<5$ & $>0.9$ & $>0.8$ & $>0.9$ & $>0.9$ & $>0.9$ \\
\hline Saturated model & & & 1.000 & & 1.000 & & 1.000 \\
\hline $\begin{array}{l}\text { Independence } \\
\text { model }\end{array}$ & 0.159 & 14.228 & 0.345 & 0.328 & 0.000 & 0.000 & 0.000 \\
\hline
\end{tabular}

Data sources included primary and secondary data. Secondary data was obtained from a previous study of the researcher, which included a series of individual interviews, focus groups, observations, and analysis of relevant documents, for the primary data, a survey questionnaire was designed to collect data, which included two sections: Section A contains demographic information for respondents, as shown in Table 4. Section B contains questions that measure the impact of a variety of factors on the delivery of citizen-centric e-government services, where respondents were asked using a 7-point Likert-type scale ranging from strongly disagree (1) to strongly agree (7) to rate their agreement or their disagreement on questions relating to those factors in the context of this study.

\subsubsection{Validity and Reliability of Research Instrument}

In order to achieve validity of research instruments, each instrument is evaluated using both convergent and discriminant validation tests. For this study, convergent validity was evaluated by examining the values of factor loadings $\left(\mathrm{R}^{2}\right)$, standardized regression coefficients and the average variance extracted (AVE). The results showed that all values were within the acceptable limits and thus confirmed the convergent validity. All instruments were significantly related to their respective factors, with standardized loading values $\left(\mathrm{R}^{2}\right)>0.5$ for each factor. Also, All standardized regression weight values were $>0.5$, and all the absolute values of critical ratios (C.R.) of all the instruments were $>1.96$, at the 0.05 level of significance. All AVE values were high and $>0.5$, which means that the instruments are truly representative of their respective factors. Following this, discriminant validity was also evaluated by comparing the squared correlation between any two factors with their respective average variance extracted (AVE). The results showed that the average variance extracted (AVE) of both factors was greater than the squared correlation between the two factors. Moreover, reliability was evaluated to ensure the internal consistency among the instruments that measure the same factor. This is usually obtained by calculating the so-called Cronbach's alpha coefficient. The lowest acceptable limit for Cronbach alpha is 0.7 [33]. Table 3 shows that all items were higher than the acceptable level of 0.7 , and therefore considered reliable for the purpose of this study.

Table 3. Reliability for all instruments in the measurement model

\begin{tabular}{|l|c|c|}
\hline \multicolumn{1}{|c|}{ Factor } & $\begin{array}{c}\text { \# of instrument } \\
\text { items }\end{array}$ & Cronbach's $\boldsymbol{\alpha}>\mathbf{0 . 7}$ \\
\hline Macro political environment & 4 items & 0.731 \\
\hline Socio economic environment & 5 items & 0.873 \\
\hline Socio cultural environment & 7 items & 0.910 \\
\hline ICT infrastructure & 6 items & 0.774 \\
\hline Legal and regulatory environment & 4 items & 0.717 \\
\hline Perceived organizational change management & 4 items & 0.761 \\
\hline Perceived organizational loyalty & 6 items & 0.721 \\
\hline Perceived organizational integration & 5 items & 0.757 \\
\hline Perceived managerial efficiency & 5 items & 0.754 \\
\hline
\end{tabular}


International Journal of Computer Science \& Information Technology (IJCSIT) Vol 6, No1, February 2014

\begin{tabular}{|l|l|l|}
\hline $\begin{array}{l}\text { Perceived IT-based intrinsic characteristics of the } \\
\text { citizen }\end{array}$ & 5 items & 0.855 \\
\hline Perceived trust in e-government services & 4 items & 0.942 \\
\hline Perceived usage aspects & 5 items & 0.806 \\
\hline Perceived quality of e-services & 6 items & 0.812 \\
\hline Perceived online safety and security & 4 items & 0.713 \\
\hline Perceived website design issues & 5 items & 0.982 \\
\hline Delivery of citizen-centric e-government services & 4 items & 0.742 \\
\hline
\end{tabular}

\subsection{Sampling}

Previous research shows that Jordanian citizens, especially the educated are among the first to adopt the Internet [30]. This means that these are likely to be users of e-government services. Accordingly, all Jordanian universities, including students, academics, and administrators were chosen to be a representative sample of the population in this study. A self-administered survey questionnaire was distributed to a total sample of 525 respondents who were selected from Jordanian universities differ among themselves in terms of the governorate, region and authority. Therefore, the Jordanian universities are not distributed equally. The north region of Jordan makes up about $34.3 \%$ of total students and about $33.8 \%$ of total administrators and academics in the total universities in Jordan, and the central region accounts for around $54.3 \%$ of total students and about $54.6 \%$ of total administrators and academics. The south region consists of $11.4 \%$ of total students and about $11.6 \%$ of total administrators and academics. Of the total survey questionnaires that were distributed; 472 were returned, achieving a response rate reached $90 \%$. 12 of those were incomplete, and therefore were excluded from any further analysis in this study. Accordingly, 460 survey questionnaires were suitable for further analysis in this research. Table 4 summarizes the demographic characteristics of the respondents in this study.

\subsection{Testing Multivariate Assumptions}

To meet the requirements of data analysis and hypotheses testing, it was necessary to evaluate the multivariate normality of the sample data using skewness and Kurtosis measures [34]. The results indicate no departure from normality. Thus, the analysis proceeded using the maximum likelihood estimation (MLE) method to estimate the proposed research model using AMOS V18.

Table 4. Demographic characteristics of respondents

\begin{tabular}{|c|c|c|c|}
\hline \multicolumn{2}{|c|}{ Characteristics } & Frequency & Percent \\
\hline Position & Academic & 37 & $8 \%$ \\
\hline & Administrator & 55 & $12 \%$ \\
\hline & Student & 368 & $80 \%$ \\
\hline Region & North & 138 & $30 \%$ \\
\hline & Central & 244 & $53 \%$ \\
\hline Gender & South & 78 & $17 \%$ \\
\hline & Male & 299 & $65 \%$ \\
\hline Age & Female & 161 & $35 \%$ \\
\hline & $<20$ & 5 & $1 \%$ \\
\hline & $20-30$ & 400 & $87 \%$ \\
\hline & $31-40$ & 23 & $5 \%$ \\
\hline & $41-50$ & 27 & $6 \%$ \\
\hline & $>50$ & 5 & $1 \%$ \\
\hline & Diploma & 9 & $2 \%$ \\
\hline & Bachelor & 414 & $90 \%$ \\
\hline
\end{tabular}


International Journal of Computer Science \& Information Technology (IJCSIT) Vol 6, No1, February 2014

\begin{tabular}{|c|c|c|c|}
\hline & Master & 9 & $2 \%$ \\
\hline & PhD & 28 & $6 \%$ \\
\hline Monthly household income (JD) & $<200$ & 9 & $2 \%$ \\
\hline & $200-500$ & 101 & $22 \%$ \\
\hline & $501-1000$ & 60 & $13 \%$ \\
\hline & $1001-1500$ & 221 & $48 \%$ \\
\hline Major & $>1500$ & 69 & $15 \%$ \\
\hline & Scientific & 354 & $77 \%$ \\
\hline & Humanities & 106 & $23 \%$ \\
\hline Has a computer at home & Yes & 405 & $88 \%$ \\
\hline & No & 55 & $12 \%$ \\
\hline & Yes & 294 & $64 \%$ \\
\hline
\end{tabular}

\subsection{Data Analysis}

To analyze the data collected, as well as test hypotheses, SEM using AMOS V18 software package was used. Table 5 shows the results of multivariate analysis with SEM, applying path tracing rules (path analysis), which is based on the relationships proposed above in the research model. Some of these relationships were acceptable in the context of this study, while others were not. Figure 2 shows a graphical representation of the analysis results of significant relationships only.

\section{RESULTS AND DISCUSSION}

As previously hypothesized, the results in Figure 2 showed that only eleven factors have had a mixed impact on the successful delivery of citizen-centric e-government services in this context, and thus accounted for $71.7 \%$ of the variance explained $\left(\mathrm{R}^{2}=0.717\right)$. The results showed that $\mathbf{H 1}$ is significant but negative in this context. This is consistent with a study of [35], which found that despite the importance of policies and strategies developed recently to promote the ICT sector in Egypt, no positive impact was found on their readiness to develop citizen-centric e-government services on a large-scale successfully. So far the political trends in most developing countries, including Jordan did not reach the level of expectations with regard to strengthening the ICT sector, and thus become a positive factor measures the success in the delivery of citizen-centric e-government services. However, the recent political reform projects will ensure the development of a national ICT policy, thereby increasing trust in the political environment and thus have a positive impact on the Jordanian citizens to accept the change towards the use of citizen-centric e-government services on a large scale. $\mathbf{H 2}$ is positive and significant in this context.

Table 5: Hypotheses testing, path loadings and critical ratios within factors in the research model (***=significance at the 0.001 level, $* *=$ significance at the 0.01 level and $*=$ significance at the 0.05 level)

\begin{tabular}{|c|l|c|c|c|c|c|}
\hline $\begin{array}{c}\text { Hypothe } \\
\text { sis } \\
\#\end{array}$ & \multicolumn{1}{|c|}{$\begin{array}{c}\text { Structural } \\
\text { Relationship }\end{array}$} & $\begin{array}{c}\text { Regressi } \\
\text { on } \\
\text { Weight }\end{array}$ & $\begin{array}{c}\text { Standar } \\
\mathbf{d} \\
\text { Error } \\
\text { (SE) }\end{array}$ & $\begin{array}{c}\text { Critica } \\
\text { I Ratio } \\
\text { (C.R.) }\end{array}$ & $\begin{array}{c}\text { P- } \\
\text { Value }\end{array}$ & Significance \\
\hline 1 & EGVDELIVY $\leftarrow$ MPE & -0.5 & 0.032 & -2.011 & $*$ & $\begin{array}{c}\text { Negatively } \\
\text { significant }\end{array}$ \\
\hline 2 & EGVDELIVY $\leftarrow$ SCE & 0.3 & 0.023 & 2.671 & $*$ & Significant \\
\hline 3 & $\begin{array}{l}\text { EGVDELIVY } \\
\text { ICTINF }\end{array}$ & -0.7 & 0.041 & -2.419 & $*$ & $\begin{array}{c}\text { Negatively } \\
\text { significant }\end{array}$ \\
\hline 4 & EGVDELIVY $\leftarrow$ SEE & -0.9 & 0.028 & -2.74 & $* *$ & Negatively \\
\hline
\end{tabular}


International Journal of Computer Science \& Information Technology (IJCSIT) Vol 6, No1, February 2014

\begin{tabular}{|c|c|c|c|c|c|c|}
\hline & & & & & & significant \\
\hline 5 & EGVDELIVY く LRE & -0.9 & 0.034 & -2.183 & $* *$ & $\begin{array}{l}\text { Negatively } \\
\text { significant }\end{array}$ \\
\hline 6 & $\begin{array}{ll}\text { EGVDELIVY } & \leftarrow \\
\text { ORGCHG } & \end{array}$ & 0.07 & 0.044 & 1.514 & 0.13 & Not \\
\hline 7 & $\begin{array}{l}\text { EGVDELIVY } \\
\text { ORGINT }\end{array}$ & 0.06 & 0.044 & 1.217 & 0.22 & Not \\
\hline 8 & $\begin{array}{ll}\text { EGVDELIVY } & \leftarrow \\
\text { ORGLOY } & \\
\end{array}$ & 0.6 & 0.047 & 1.983 & $* *$ & Significant \\
\hline 9 & EGVDELIVY $\leftarrow \mathrm{ME}$ & 0.07 & 0.035 & 0.147 & 0.88 & Not \\
\hline 10 & $\begin{array}{l}\text { EGVDELIVY } \\
\text { CZINTCHAR }\end{array}$ & 0.8 & 0.021 & 2.814 & $* *$ & Significant \\
\hline 11 & $\begin{array}{l}\text { EGVDELIVY } \\
\text { EGOVTRST }\end{array}$ & 0.7 & 0.056 & 2.420 & $* *$ & Significant \\
\hline 12 & $\begin{array}{l}\text { EGVDELIVY } \\
\text { CZUSGASP }\end{array}$ & 0.01 & 0.034 & 0.291 & 0.77 & Not \\
\hline 13 & $\begin{array}{l}\text { EGVDELIVY } \\
\text { EGOVQLTY }\end{array}$ & 0.5 & 0.065 & 3.332 & $*$ & Significant \\
\hline 14 & $\begin{array}{l}\text { EGVDELIVY } \\
\text { ONSAFSEC }\end{array}$ & 0.5 & 0.041 & 2.906 & $*$ & Significant \\
\hline 15 & $\begin{array}{l}\text { EGVDELIVY } \\
\text { WEBDSGN }\end{array}$ & 0.6 & 0.044 & 3.035 & $*$ & Significant \\
\hline
\end{tabular}

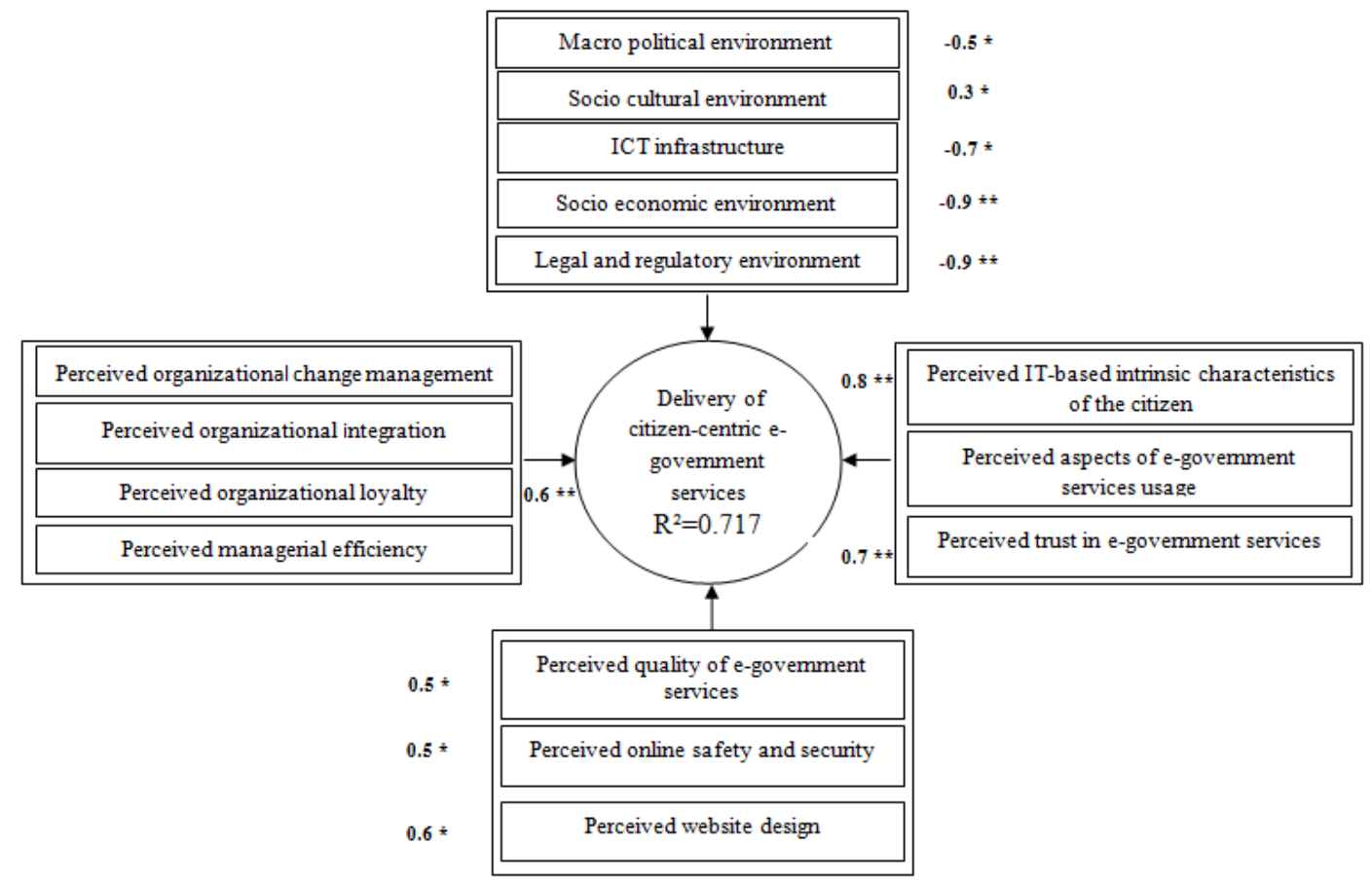

Figure 2. Significant relationships in the research model

This result is inconsistent with some previous studies [22][36][37][38], which showed a negative relationship between national culture and change towards the successful delivery of citizencentric e-government services in different developing countries. However, openness in recent years to the world through the channels of social networking Facebook and Twitter have made technology a prerequisite and not secondary to life for most developing countries, including 
Jordan, and thus the results showed that the characteristics of modern Arab culture has become among the positive predictors to accept the change, and thus the transfer of technology to those communities. $\mathbf{H 3}$ is significant but negative in this context. This result is consistent with some other studies [39][40], which indicated that the lack of ICT infrastructure will impact negatively on the support and enable e-government projects in the developing world. In other words, without the ICT infrastructure, the delivery of e-government services becomes pure fantasy. Similarly, [41] indicated that the adequacy of ICT infrastructure is among the critical success factors for egovernment implementation at both the local and national level. Over the years, most developing countries, including Jordan has long suffered from poor ICT, and thus had a negative impact on the success of the IT transfer to these communities. But now, Jordan has witnessed a remarkable development in the ICT infrastructure in the past few years. Also, the rise in the number of mobile phone users has provided technological alternatives for citizens to access the Internet. Knowledge stations are also of the achievements of the Jordanian government to establish access points in all parts of the Kingdom to take advantage of Internet services. Lower prices for Internet services in Internet cafes make it an alternative for people to access the Internet with different causes of usage. These will make the ICT infrastructure in Jordan and other similar developing countries among the positive and significant factors to measure the success of the delivery of egovernment services.

H4 is significant but negative in this context. This result is partly consistent with a study of [42], which found that some socio-demographic characteristics such as age and sex showed significance in the adoption of broadband in a local community (the London Borough of Hillingdon) in the UK, while the characteristics such as education and income did show significance in the same context. Similarly, [43] showed significance between some of the socioeconomic factors (e.g. education and economic wealth) and the ability of African regions to leverage ICT products and services for development and growth. [44], through the study of a total of 54 socioeconomic factors found that $50 \%$ of these factors (e.g. IT literacy, high rate of inflation, unfavourable exchange rate of the naira to the dollar, low wage level, huge costs, low gross national product, inadequate funding) showed significance in influencing the successful adoption and implementation of ICT in the Nigerian print media. Others pointed to the importance of some of the socioeconomic factors such as access issues and digital divide on the successful delivery of e-government services [45][46]. However, Jordan is one of the most stable countries in the Arab region in political terms in the past two years. This has made Jordan as an attractive destination for investments, as well as a place for development projects serving the region as a whole and helps to bridge the gap between the countries of the Eastern and Western worlds, except for some Asian countries such as Singapore and Japan. In simple terms, foreign investments, openness, deregulation and privatization were among the outcomes of these projects, which contributed greatly to the impact on the socioeconomic environment in Jordan through the provision of more job opportunities for Jordanians and to improve the facilities and services provided to citizens in various fields. Jordan is also one of the first Arab countries that eliminated illiteracy, $95 \%$ of young people aged between 18 and 24 years are studying in different stages, while the rate of illiteracy among adults does not exceed $10 \%$. With respect to IT literacy, Jordan has witnessed the application of a number of e-initiatives (e.g. knowledge stations and e-villages) to bridge the digital divide between cities and villages in the kingdom. These will make the socioeconomic environment in Jordan and other similar developing countries among the positive factors to accept the change and thus the success of the delivery of citizen-centric e-government services.

H5 is significant but negative in this context. This result is consistent some previous studies [47][48], which pointed to the importance of developing the legal and regulatory environment to support and enable e-government in the developing world. Others, such as [49] indicated that despite all the programs of political reform in the developing world, legal and regulatory 
framework is still not developed as in the Western world, where there are no restrictions on the structures of investment, protection and enforcement of intellectual property rights, privacy, security and legal recognition of e-interactions and e-signatures. However, Jordan is not an exception; the legal and regulatory framework is not developed enough to support the delivery of e-government services successfully at all levels. Therefore, more attention from decision-makers towards the laws and legislation governing e-transactions will make this factor among the positive factors to accept the change and thus success in the delivery of e-government projects in the context of the research, unlike the results.

H6 is positive but insignificant in this context. This result is inconsistent with some previous studies [21][50][51], which pointed to the importance of the process of change mangement, including plan for change, support for change, training for change and effective communication for change, resistance management to change, to support and enable e-government delivery at all levels. Those surveyed in this study believe that the most important requirement for the success of the change and transfer of IT to these communities is the qualified human factor. This usually does not need to awareness-raising and training programs to adapt to the new technological environment, and thus explains part of the positive relationship but with no significance in this context. On the other hand, and from another point of view, the provision of adequate support for those governments politically, economically and socially at all levels to manage the change would make this factor among the significant factors and thus contribute to the successful delivery of large-scale projects such as e-government in this context. Jordan, as mentioned previously has begun projects for national reform, which have a positive impact on the effectiveness of the government role in support of the change and the successful transfer of IT to those communities.

H7 is positive but insignificant in this context. This result is consistent with a study of [52], which pointed out that technological factors, including the integration of government systems may not guarantee the success of e-government delivery, but along with the availability of adequate resources, appropriate infrastructure, management support, capable IT staff, effective IT training and IT support may increase the chances of success in developing countries. Despite the political reforms, technological progress and the adequacy of the technological infrastructure that Jordan witnessed recently, organizational integration has not reached the level that it becomes significantly affect the success of e-government delivery at all levels. Another reason could be the technical nature of the factor, which may not be familiar, and of concern to citizens, especially the study sample, leading to inaccuracies in the responses.

H8 is positive and significant in this context. This result is consistent with some previous studies [53][54], which concluded that participation in the decision-making process creates a sense of belonging and loyalty to the organization, even if not great. Similarly, [55] found that since egovernment is a socio-technical system, greater participation in all phases of delivery, deployment, are even more necessary for its success. In addition, [14] pointed to the importance of awareness-raising campaigns to promote the participation of citizens in the process of change towards the success of e-government delivery. Similarly, [23] showed that governments in developing countries such as Pakistan should run extensive advertising campaigns to ensure that people are aware of the services and use them. This implies that government should place emphasis on increasing awareness of the new e-services, show the benefits of citizens, and encouraging trust in the system. In spite of what is known about the Arab culture unwillingness to participate in political life, the results confirm that this fear has dissipated and that the political participation in decisions has become clear, as is the case in Jordan. Accordingly, organizational loyalty is seen in Jordan and other similar developing countries as one of the significant factors to accept the change and thus the success of e-government delivery. 
H9 is positive but insignificant in this context. This result is partly consistent with two studies. [56][64] found that some organizational and managerial factors did not show significance on the success of e-government delivery such as top management support, while others, such as goals alignment, management style, managerial IT knowledge and decentralisation of decision-making structure showed significance in the same context. [53] showed that facilitating conditions had no significance on usage behaviour of the e-tax filing and payment system in Mauritius, as an example of an e-government service. As mentioned previously, Jordan has witnessed positive changes because of political reform programs in the past few years. For example, there are many independent bodies to monitor government performance, whose members are selected by the head of state, and characterised by professionalism and high integrity. These have had an impact on the citizens but not at the level required to be significantly influential on the success of egovernment delivery.

H10 is positive and significant in this context. This result is consistent with some previous studies [22][57], which indicated that the intrinsic characteristics of the user such as motivation, knowledge, experience, beliefs, attitudes, IT risk taking and innovativeness, directly affect the decision to accept the change towards success in the delivery of e-government services. [20] pointed to the mixed influence of socio-demographic factors on the decision to accept the change towards the successful delivery of e-government. Among the negative factors were age and gender (female), while the positive factors were Internet experience, education, gender (male), occupation and income. H10 is consistent with previous hypotheses, particularly. H2, which showed that the culture of the Jordanian citizen has become more open to the world than it was in the past and accept the change, which could lead to accelerate the transfer of IT in such communities.

H11 is positive and significant in this context. This result is consistent with some previous studies [1][29][58][64], which indicated that there is a positive and significant relationship between the citizen's trust in e-services and the intention to adopt and use these services, for example, egovernment. Over the years, there has been a lack of trust relationship between most governments and their citizens in the context of developing countries, including Jordan, regarding the management and delivery of large-scale projects. But, as a result of reform programs in the governmental sector, including partnerships with the private sector for the delivery of the IT sector, which have been recently taken, trust between citizens and governments in those countries, including Jordan has become stronger, leading to a positive relationship in this context. In other words, to ensure the successful implementation of citizen-centric e-government services, trust is imperative between all parties, namely the government sector, the private sector and most importantly the citizens. $\mathbf{H 1 2}$ is positive but insignificant in this context. This result is consistent with a study of [59], which indicated that perceived ease of use and perceived usefulness are not among the significant factors that affect the citizens to adopt and then use the e-government services. Similarly, the result is also consistent with a study of [60], which found computer selfefficacy as an insignificant predictor in influencing the use of e-government in Mauritius. Perceived usage aspects of e-government including ease of use, usefulness, self efficacy and peer influence, all of these are no longer significant predictors to the Jordanian citizens to accept the change towards the delivery of e-government. The reasons why there is no relationship may be the lack of cultural awareness of the new e-government services and applications, the penetration of mobile phones and Internet have increased the professionalism in dealing with IT-based technologies, which means that these are becoming more familiar and thus easier to handle than ever. Accordingly, the impact of perceived ease of use and self efficacy are dropped in this context. Also, e-government differs from e-commerce in terms of usage; this means that government services are compulsory for citizens, whether useful or not and this scenario is not accurate for this context. 
H13 is positive and significant in this context. This result is consistent with some previous studies [50][61][62], which found that the quality of e-services provided (e.g. creativity, transparency, availability, functionality, accessibility, timeliness, support, interactivity, and responsiveness) has a direct and positive impact on the decision to accept change towards the delivery of egovernment in different contexts. However, quality of e-government in this context can be perceived by the following: highly responsive to citizens'calls, enabling citizens to track their queries until resolved without difficulty, having e-government services and applications available 24/7, having a single point of access to all government information and services, and enabling better interaction with the government (e.g. online feedback and knowledge sharing).

H14 is positive and significant in this context. This result is consistent with some previous studies [6][38][63], which found that online security has a direct impact on the implementation and deployment of e-government services. Perceived Online safety and security is among the significant predictors to the Jordanian citizens to accept the change towards the delivery of egovernment. This result is expected and consistent with the result of H5, where those who were surveyed pointed to the need for a legal and regulatory framework to ensure safety and security of Internet users with regard to conduct transactions electronically. Thus, the importance of safety and security on the Internet has become a necessity to ensure the successful delivery of egovernment services in developing countries, including Jordan.

H15 is positive and significant in this context. This result is consistent with some previous studies [27][29], which indicated a positive and significant relationship between the characteristics of egovernment websites including the usability, accuracy, relevancy, navigability, customisation, completeness, precision, multilingual, and modality, and the decision to accept the change towards the delivery of e-government in different contexts. However, Jordan, and over the past few years, has witnessed political reforms. These reforms have strengthened the concept of democratic life and raised the level of organizational loyalty as shown in H8, which reflected positively on the characteristics of e-government websites by allowing greater participation of citizens than ever in governance issues on the one hand, and on the other hand have changed some of the negative characteristics of Arab culture, which was prevalent on the violation of data privacy especially when conducting online transactions, all these positively affect change towards success in the delivery of e-government in this particular context.

\section{Theoretical and Practical Implications}

Theoretically, this two-phase research contributes to the existing knowledge through the following: 1) the application of multiple research methods; grounded theory method along with interpretive case studies to develop an integrated research model, and a survey questionnaire method to test and validate the research model using multivariate and SEM, 2) expand the level of analysis, including all potential players of various categories (public sector, private sector, and most importantly, citizens) to enable in-depth understanding and gain valuable insights about the success factors for the delivery of citizen-centric e-government services, 3) the application of SEM using path tracing rules (path analysis) in this context, and most importantly 4) summarize the success factors that affect the delivery of citizen-centric e-government services from multiple perspectives, and in the context of developing countries, including Jordan. For example, the results showed that the national e-readiness is not as intended, where the results pointed to weakness in ICT infrastructure, as well as the legal and regulatory framework that governs the exchange of information and transactions over the Internet. At present, these factors showed significance, but in a negative impact on the delivery of citizen-centric e-government services in Jordan. This means that when a citizen feels that there are policies and strategies to support ereadiness for a smooth transfer of ICT to the community, this creates a high level of satisfaction and then lead to the decision to take advantage of e-government services. Most previous studies pointed to the negative impact of Arab culture on the ICT transfer, but Jordan, through this study, 
has shown that ICT has become is one of the characteristics of modern culture of the Jordanian society and thus has a positive impact on the decision to take advantage of e-government services. Also, openness to the outside world was accompanied by a change in the ideologies where citizens have become more enthusiastic to participate in the change, namely political participation. This means that when citizens feel of belonging and participation in the decisionmaking process, this creates a high degree of satisfaction and then leads to the decision to take advantage of e-government services. This study also showed that the quality, trust of egovernment services, good design of government websites and online safety and security, all of these are among the positive factors that affect on the delivery of citizen-centric e-government services in this particular context. Most importantly, the results showed that perceived ease of use and perceived usefulness are no longer among the factors that affect the delivery of citizencentric e-government services in the same context. This confirms that the prevailing models and theories about IT innovation on a large scale, do not apply equally to the context of developing countries, thus do not explain and predict the success factors in the delivery of e-government services in the context of this study. Practically, this two-phase research provides a strategic tool for decision-makers, government officials and practitioners in developing countries, including Jordan, to evaluate the success factors in the delivery of citizen-centric e-government services from multiple perspectives. This would contribute to the understanding of key issues affecting the needs of citizens and the level of satisfaction with the new public services. The results showed that the technical factors are not only responsible for the success of citizen-centric e-government services, but also goes beyond that to include other organisational (governmental), individual and contextual factors for doing so. In simple terms, governments in the Arab region can benefit from the tool in the development of new evaluation methods, based on the measures resulting from the grounded theory study, to determine whether there are barriers affect the success in the delivery of citizen-centric e-government services and thereby take the necessary action to remove it, when needed. To ensure the success in the delivery of citizen-centric e-government services in this context, the government needs to take the following actions: 1) to build a national policy for the development of the ICT sector, 2) to update laws and legislation that protects Internet users and organise exchange of information over the Internet, 3) to support and enable the development of ICT infrastructure in terms of infrastructure accessibility, infrastructure reliability, infrastructure availability and infrastructure support and maintenance, 4) to include both the technical and nontechnical design aspects of e-government websites such as increased citizen participation in governance issues. These and many other aspects represent important values for Jordanian citizens to support change towards the adoption and implementation of citizen-centric egovernment services, 5) to maintain the quality of e-government services as a determinant of the citizen's trust in e-government, so taking into account quality of e-government measures (e.g. high response to citizens' calls, enabling citizens to track their queries until resolved without difficulty, having e-government services and applications available $24 / 7$, having a single point of access to all government information and services, and enabling better interaction with the government (e.g. online feedback and knowledge sharing) would ensure a high level of satisfaction among the citizens for the adoption and implementation of citizen-centric egovernment services, 6) to manage online safety and security risks, this would boost trust in egovernment services and thus the success in its delivery at all levels, 7) to increase the role of citizens in governance issues by holding regular meetings with citizens. Although some of the values and practices that limit the political participation of citizens, the desire for the majority of citizens to change and nothing but the change is one of the most important determinants of the success of e-government in Arab societies in general and Jordan in particular, and finally 8) to increase citizens' awareness of e-government services and applications by providing incentives and rewards, intensifying promotional campaigns through various communication media, particularly SMS-based e-government marketing due to high mobile penetration in Jordan. In such contexts, focusing on e-government via mobile is likely to be a key way forward, particularly in the medium term. 


\section{RESERACH MODEL EVALUATION}

Table 6 below provides an assessment of the individual factors proposed in the research model with an illustrative example of the Income and Sales Tax Department in the development of citizen-centric e-government services in Jordan.

Table 6. Research model evaluation using an illustrative example of income and sales tax citizen-centric egovernment services

\begin{tabular}{|c|c|c|c|}
\hline Factor & Impact & Level & Requires \\
\hline \multirow[t]{2}{*}{$\begin{array}{l}\text { Political commitment to } \\
\text { ensure "buy in" by } \\
\text { government entities across } \\
\text { government }\end{array}$} & \multirow[t]{2}{*}{ High } & \multirow[t]{2}{*}{ National } & $\begin{array}{l}\text { Activate the National e-Government } \\
\text { Steering Committee eGSC to direct e- } \\
\text { government implementations }\end{array}$ \\
\hline & & & $\begin{array}{l}\text { Engagement by political leaders and } \\
\text { MoICT; empowerment of e-Government } \\
\text { Program }\end{array}$ \\
\hline \multirow{3}{*}{$\begin{array}{l}\text { Availability of resources } \\
\text { (HR) including availability } \\
\text { of local skills to implement } \\
\text { and use e-Transformation }\end{array}$} & \multirow{3}{*}{ High } & \multirow{3}{*}{$\begin{array}{l}\text { Governmental/ } \\
\text { Citizen }\end{array}$} & Commitment by Government of Jordan \\
\hline & & & $\begin{array}{l}\text { Develop courses/workshops locally } \\
\text { School/ College/ University to re-skill } \\
\text { and train people }\end{array}$ \\
\hline & & & $\begin{array}{l}\text { Incentives to e-Government stakeholders } \\
\text { to strengthen e-Transformation related } \\
\text { skills }\end{array}$ \\
\hline $\begin{array}{l}\text { Availability of Laws and } \\
\text { regulations that support the } \\
\text { implementation of e- } \\
\text { Transformation }\end{array}$ & High & National & $\begin{array}{l}\text { Active coordination among targeted } \\
\text { agencies to develop and enforce } \\
\text { coherent and effective legal and } \\
\text { regulatory framework }\end{array}$ \\
\hline \multirow[t]{3}{*}{$\begin{array}{l}\text { Availability of } \\
\text { infrastructure }\end{array}$} & \multirow{3}{*}{ High } & \multirow{3}{*}{ National } & $\begin{array}{l}\text { develop one stop portal, in both } \\
\text { languages Arabic and English }\end{array}$ \\
\hline & & & $\begin{array}{l}\text { Create e-kiosks that are connected to the } \\
\text { portal, so those who do not have Internet } \\
\text { can access the e-services easily }\end{array}$ \\
\hline & & & $\begin{array}{l}\text { SMS gateway that enable providing } \\
\text { services via mobile }\end{array}$ \\
\hline \multirow{3}{*}{$\begin{array}{l}\text { Cooperation and harmony } \\
\text { among government entities } \\
\text { in decision making for e- } \\
\text { Transformation initiatives }\end{array}$} & & \multirow{3}{*}{ Governmental } & $\begin{array}{l}\text { Appoint more influential National e- } \\
\text { Government Steering Committee eGSC }\end{array}$ \\
\hline & & & Appoint CIO Council \\
\hline & Medium & & $\begin{array}{l}\text { Inter-agency working groups with clear } \\
\text { authority over defined e-Transformation } \\
\text { initiatives }\end{array}$ \\
\hline
\end{tabular}




\begin{tabular}{|c|c|c|c|}
\hline $\begin{array}{l}\text { Ability and readiness of } \\
\text { government entities to } \\
\text { document and share their } \\
\text { business requirements, } \\
\text { processes, services, data } \\
\text { and strategies }\end{array}$ & Medium & Governmental & $\begin{array}{l}\text { Active coordination among government } \\
\text { entities to document and share } \\
\text { information necessary for e-Government } \\
\text { initiatives }\end{array}$ \\
\hline $\begin{array}{l}\text { Private sector capacity to } \\
\text { participate in / support e- } \\
\text { Transformation }\end{array}$ & High & Governmental & Active public private partnership (PPP) \\
\hline \multirow[b]{2}{*}{$\begin{array}{l}\text { Identifying citizens } \\
\text { priorities and needs }\end{array}$} & \multirow[b]{2}{*}{ High } & \multirow[b]{2}{*}{ National/citizen } & Citizens profiling \\
\hline & & & $\begin{array}{l}\text { launch a national contact centre for } \\
\text { government services to increase } \\
\text { communication and a communication } \\
\text { centre via email named 'ASK' }\end{array}$ \\
\hline \multirow{3}{*}{$\begin{array}{l}\text { Supervising, auditing, } \\
\text { checking and reporting the } \\
\text { performance of the e- } \\
\text { government } \\
\text { implementations in terms of } \\
\text { quality, risks and security } \\
\text { issues }\end{array}$} & \multirow{3}{*}{ High } & \multirow{3}{*}{$\begin{array}{l}\text { Governmental/ } \\
\text { Technological }\end{array}$} & $\begin{array}{l}\text { Develop technical strategies, concept } \\
\text { and standards for e-government } \\
\text { implementations }\end{array}$ \\
\hline & & & $\begin{array}{l}\text { Establish CERT (Computer Emergency } \\
\text { Response Team); creating information } \\
\text { security eligibility criteria and } \\
\text { developing business continuity plan }\end{array}$ \\
\hline & & & $\begin{array}{l}\text { greater care in designing e-government } \\
\text { websites }\end{array}$ \\
\hline \multirow{4}{*}{$\begin{array}{l}\text { Sustainability of e- } \\
\text { Government } \\
\text { implementation despite } \\
\text { political changes and } \\
\text { reshuffle of government } \\
\text { officials }\end{array}$} & \multirow{4}{*}{ High } & \multirow{4}{*}{ National } & $\begin{array}{l}\text { Appoint and activate the National e- } \\
\text { Government Steering Committee eGSC }\end{array}$ \\
\hline & & & $\begin{array}{l}\text { Passage of e-Gov regulations and other } \\
\text { actions to secure endorsement at top } \\
\text { levels of government }\end{array}$ \\
\hline & & & $\begin{array}{l}\text { Development of "champions" at key } \\
\text { ministries / entities; development of } \\
\text { administrative will for e-Government } \\
\text { initiatives }\end{array}$ \\
\hline & & & $\begin{array}{l}\text { Recognition of e-Government as a } \\
\text { priority in National Agenda }\end{array}$ \\
\hline
\end{tabular}

\section{LIMITATIONS}

As in all previous research, this study also has its limitations. It is based on cross-sectional data collection design, so it may be difficult to know whether the effect of the proposed success factors will be constant or variable over time. Accordingly, it would be useful in future research if longitudinal data were collected to overcome such a limitation. In addition, this study is based on 
a representative sample of the Jordanian society to validate the proposed hypotheses about the success factors for the delivery of citizen-centric e-government services in the context of developing countries in general and Jordan in particular. This sample is composed of students, academics and administrators in Jordanian universities. Despite the stated rationale for the selection of this sample of this research, there are still other groups of Jordanian community such as illiterate and those with special needs (disabled people), which may have different needs and demands of change for the adoption and implementation of e-government services. However, validation of hypotheses by choosing other samples from the study population, such as those mentioned would generalize the results to other groups of the same context, without exceptions.

\section{Conclusions}

This study employs a holistic approach to enable in-depth understanding and gain valuable insights on the critical success factors for the delivery of citizen-centric e-government services in the context of developing countries in general and Jordan in particular from multiple perspectives, namely the national, governmental, citizen and technological perspective. The results of a multivariate analysis using SEM showed that the national e-readiness of developing countries, including Jordan, in terms of policies, laws, legislation and infrastructure, among the success factors that affect the delivery of citizen-centric e-government services on a large scale. Modern Arab culture characterized by openness to the outside world more than ever, is also among the success factors for the delivery of citizen-centric e-government services on a large scale. In addition, perceived organizational loyalty through greater participation in the political decisions that concern the citizens on the one hand, and on the other to increase the incentives to build positive attitudes towards awareness of governments and all provided by them to citizens, such as e-services, would lead to success in the delivery of those citizen-centric e-government services on a large scale. The results also showed that perceived quality of e-government services, trust, e-government websites design and online safety and security, all of these are among the success factors that affect the delivery of citizen-centric e-government services in this study context. Most importantly, the results showed that perceived ease of use and perceived usefulness are no longer among the success factors that affect the delivery of citizen-centric egovernment services in this particular context. This confirms that the prevailing models and theories about IT innovation on a large scale, do not apply to the context of developing countries as in developed countries, and therefore does not reflect the same success factors for the delivery of citizen-centric e-government services, including the context of this study. With governments continue to invest in e-government services in developing countries, including Jordan, their understanding of the success factors has become among the key requirements that would positively impact on the delivery of these services for e-government on a large scale.

\section{ACKNOWLEDGEMENTS}

The author is grateful to the Applied Science University, Amman, Jordan, for the financial support granted to cover the publication fee of this research article.

\section{REFERENCES}

[1] Belanger, F. \& Carter, L. (2008), Trust and risk in e-government adoption, Journal of Strategic Information Systems, 17 (2), 165-176

[2] Almahamid, S., Mcadams, A., Al Kalaldeh, T. \& Al-Sa'eed, M. (2010), The Relationship between Perceived Usefulness, Perceived Ease of Use, Perceived Information Quality, and Intention to Use EGovernment, Journal of Theoretical and Applied Information Technology, 11(1), 30-44

[3] Fang Zhao, Annibal José Scavarda, Marie-France Waxin, (2012) "Key issues and challenges in egovernment development: An integrative case study of the number one eCity in the Arab world", Information Technology \& People, 25(4), 395 - 422

[4] Fu, J. R. Farn, C. K. \& Chao, W. P. (2006), Acceptance of Electronic Tax Filing: A Study of Taxpayer Intentions, Information \& Management, 43, 109-126 
[5] Al-Nagi, E. \& Hamdan, M. (2009) Computerization and e- Government implementation in Jordan: Challenges, obstacles and successes, Government Information Quarterly, 26, 577-583

[6] Al-Awadhi, S., \& Morris, A. (2009), Factors influencing the adoption of e-government services, Journal of Software, 4(6), 584-590

[7] Fraser, C. (2009), E-government: The Canadian experience, Dalhousie Journal of interdisciplinary management (DJIM), $\quad$ Vol $\quad$ s, http://djim.management.dal.ca/issue_pdfs/Vol4/Fraser_The_Canadian_Experience.pdf

[8] Runiewicz, M. Wardyn, L. Polanski, P. Piatkowski, M. \& Tomkiewicz, J., (2008), The Development of eServices in an Enlarged EU: eGovernment and eHealth in Poland, JRC scientific and technical reports, European Commission Joint Research Centre Institute for Prospective Technological Studies European commission, http://ftp.jrc.es/EURdoc/JRC49204.pdf

[9] Shareef, M.A., Kumar, U., Kumar, V. and Dwivedi, Y.K. (2009), Identifying critical factors for adoption of e-government', Electronic Government, An International Journal, 6(1), 70-96

[10] Gallant, L. Culnan, M. \& McLoughlin, P. (2007), Why People e-File (or Don't e-File) Their Income Taxes, Proceedings of the 40th Hawaii International Conference on System Sciences, Big Island, Hawaii, USA, 3-6 January 2007, pp107-112

[11] Heeks, R. \& Bailur, S. (2007), Analyzing e-government research: perspectives, philosophies, theories, methods, and practice, Government Information Quarterly, 24(2), 243-65

[12] Yildiz, M. (2007), E-government Research: Reviewing the Literature, Limitations, and Ways Forward, Government Information Quarterly, 24(3), 646-665

[13] Wangpipatwong, S. Chutimaskul, W. \& Papasraton, B. (2008), Understanding citizen“s continuance intention to use e-government website: a composite view of technology acceptance model and computer self-efficacy, The Electronic Journal of E-Government, 6(1), 55-64

[14] Weerakkody, V. El-Haddadeh, R. \& Al-Shafi, S. (2011), Exploring the complexities of e-government implementation and diffusion in a developing country: Some lessons from the State of Qatar, Journal of Enterprise Information Management, 24(2), 172 - 196

[15]Chen, Y. N., Chen, H. M., Huang, W. \& Ching, R. K. H. (2006), E-government strategies in developed and developing countries: an implementation framework and case study. Journal of Global Information Management, 14(1), 23-46

[16] Rogers, EM. (1995) Diffusion of Innovations, (4th Eds.), Free Press, New York, NY

[17] Davis, F. D. Bagozzi, R. P. \& Warshaw, P. R. (1989), User acceptance of computer technology: a comparison of two theoretical models, Management Science, 35(8), 982-1003

[18] Venkatesh, V. \& Davis, F. D. (2000), A theoretical extension of the Technology Acceptance Model: four longitudinal field studies, Management Science, 46 (2), 186-204

[19] Triandis, H. C. (1980), Values, attitudes, and interpersonal behavior, in M. M. Page (Eds.), 1979 Nebraska symposium on motivation: Beliefs, attitudes, and values 27, 195-259, Lincoln, NE: University of Nebraska Press

[20] Reddick, C.G. (2005), Citizen interaction with e-government: From streets to servers? Government Information Quarterly, 22(1), 38-57

[21] Weerakkody, V. Dwivedi, Y. K. Brooks, L. \& Williams, M.D. (2007), E-government implementation in Zambia: contributing factors, Electronic Government: An International Journal, 4(4), 484-508

[22] Kumar, V. Mukerji B, Butt I \& Persaud, A. (2007), Factors for Successful e-Government Adoption: a Conceptual Framework, Electronic Journal of e-Government, 5(1), 63 - 76

[23] Ovais, M. Jouni Markkula, A. Oivo, M. (2013) "Factors affecting e-government adoption in Pakistan: a citizen's perspective", Transforming Government: People, Process and Policy, 7(2), 225 - 239

[24] AlShihi, H. \& McGrath, G.M. (2004), The Oman E-Government Project: Technology Adoption and Diffusion, Proceedings of the 18th Annual Conference of the Australian and New Zealand Academy of Management. (Eds.) Graham Elkin, University of Otago, Dunedin, New Zealand, pp. 1-16

[25] Al-Awadhi, S., Morris, A. (2008), The Use of the UTAUT Model in the Adoption of E-government Services in Kuwait, Proceedings of the 41 st Hawaii International Conference on System Sciences, pp. $1-11$

[26] Al-Shafi, S. Weerakkody, V. \& Janssen, M. (2009), Investigating the Adoption of eGovernment Services in Qatar Using the UTAUT Model, AMCIS 2009 Proceedings, Paper 260

[27] Alateyah, Suilaiman, Crowder, Richard M. and Wills, Gary B. (2013), Factors Affecting the Citizen's Intention to Adopt E-government in Saudi Arabia. World Academy of Science, Engineering and Technology, 81, 601-606. 
[28] Mofleh, S. I. \& Wanous, M. (2008), Understanding factors influencing citizens' adoption of egovernment services in the developing world: Jordan as a case study, INFOCOM-Journal of Computer Science, 7(2), 1-11

[29] Alomari, M., Sandhu, K., \& Woods, P. (2010), Measuring Social Factors in E-government Adoption in the Hashemite Kingdom of Jordan. International Journal of Digital Society (IJDS), 1(2), 163-172

[30] Al-Hujran, O. Al-dalahmeh,M. and Aloudat, A. (2011), The Role of National Culture on Citizen Adoption of eGovernment Services: An Empirical Study, Electronic Journal of e-Government, 9(2), $93-106$

[31] Anderson, J.C. and Gerbing D.W. (1988): Structural Equation Modeling in Practice: A Review and Recommended Two - Step Approach. Psychological Bulletin, 103(3), 411-423.

[32] Hair, J. Babin, B. Money, A. H. \& Samouel, P. (2003), Essentials of Business Research Methods, John Wiley \& Sons, Inc

[33] Hair, J. Black, B. Babin, B. Anderson, R. E. \& Tatham, R. L. (2006), Multivariate data analysis (6th Eds.), Englewood Cliffs: Prentice Hall

[34] Mardia, K.V. (1974), Applications of some measures of multivariate skewness and kurtosis in testing normality and robustness studies, Sankhya, Ser. B 36(2), 115-128

[35] Azab, N. A., Kamel, S. \& Dafoulas, G. (2009), A Suggested Framework for Assessing Electronic Government Readiness in Egypt, Electronic Journal of e-Government, 7(1), 11 - 28

[36] Heeks, R. (2002), Failure, Success and Improvisation of Information Systems Projects in Developing Countries, Development Informatics Working Paper Series, No.11/2002, Manchester: Institute for Development Policy and Management.

[37] Schuppan, T. (2009). "E-government in developing countries: Experiences from sub-Saharan Africa", Government Information Quarterly, 26(1), 118-127

[38] Bwalya K. J. and Healy, M. (2010), Harnessing e-Government Adoption in the SADC Region: a Conceptual Underpinning, Electronic Journal of e-Government, 8 (1), 23-32

[39] Zaied A. N. H, Khairalla, F. A. \& Al-Rashid, W. (2007), Assessing e-Readiness in the Arab Countries: Perceptions Towards ICT Environment in Public Organisations in the State of Kuwait, The Electronic Journal of e-Government, 5(1), 77-86

[40] Yonazi, J, Sol, H and Albert Boonstra, A. (2010), Exploring Issues Underlying Citizen Adoption of eGovernment Initiatives in Developing Countries: The Case of Tanzaniall Electronic Journal of eGovernment, 8(2), 176-188

[41] Sinjeri, L. Vrcek, N. \& Bubas, G. (2010), E-government development in Croatia: ICT infrastructure, management, and human capital at local level, MIPRO, Proceedings of the 33rd International Convention, 1148-1153, IEEE

[42] Choudrie, J. \& Dwivedi, Y. (2004), Investigating the Socioeconomic Characteristics of Residential Consumers of Broadband in the UK, Proceedings of AMCIS 2004, New York, USA, August 6-8, $1558-1567$

[43] Ifinedo, P. (2008), The Impacts of Socioeconomic and Cultural Factors on the Network Readiness of Nations: A Focus on the Regions of Africa, 14th Americas Conference on Information Systems (AMCIS 2008), Toronto, Canada, 14 -17 August 2008, 1-10

[44] Ehikhamenor, F. (2002), Socioeconomic factors in the application of information and communication technologies in Nigerian print media. Journal of the American Society for Information Sciences and Technology, (53)7, 602-611

[45] Aldrich, D. Bertotm, J. C. \& McClure, C. R. (2002), E-Government: initiatives, developments, and issues, Government Information Quarterly, 19 (4), 349-355

[46] Carter, L. \& Belanger, F. (2005), The utilization of e-government services: Citizen trust, innovation and acceptance factors, Information Systems Journal, 15(1), 5-25

[47] Ciborra, C. \& Navarra, D. (2005), Good Governance, Development Theory, and Aid Policy: Risks and Challenges of E-Government in Jordan, Information Technology for Development, 11(2), 141159

[48] Zaied, A. (2008), Strategic Planning for e-Development in Developing Countries, International Arab Journal of Information Technology, 5(2), 109-114

[49] Ndou, V.D. (2004), E-Government for Developing Countries: Opportunities and Challenges, Electronic Journal of Information Systems in Developing Countries, 18(1), 1-24

[50] Altameem, T. Zairi, M. \& Alshawi, S. (2006), Critical success factors of e-government: A proposed model for e-government implementation, Proceedings Conference on Innovations in Information Technology, IEEE, 1-5 
[51] Reddick, C. G. (2011), Customer Relationship Management (CRM) technology and organizational change: Evidence for the bureaucratic and e-Government paradigms, Government Information Quarterly, 28(3), 346-353

[52] Ebrahim, Z. \& Irani, Z. (2005), E-Government adoption: architecture and barriers, Business Process Management Journal, 11(5), 589-611

[53] Mahadeo, J. D. (2009), Towards an Understanding of the Factors Influencing the Acceptance and Diffusion of e- Government Services, Electronic Journal of e-Government, 7(4), 391 - 402

[54] Axelsson, K. Melin, U. \& Lindgren, I. (2010), Exploring the importance of citizen participation and involvement in e-government projects: Practice, incentives, and organization, Transforming Government: People, Process and Policy, 4(4), 299-321

[55] Jansen, A. (2006), High level strategies for user involvement in e-Government projects: What role has Scandinavian IS tradition in eGovernment implementations, available on www.jus.uio.no/ifp/om/organisasjon/afin/forskning/.../Nordichi-2006.pdf

[56] Hussein, R., Mohamed, N., Ahlan, A., Mahmud, M., \& Aditiawarman, U. (2009), Modeling G2C Adoption in Developing Country: A Case Study of Malaysia, Proceedings of the Fifteenth Americas Conference on Information Systems, San Francisco, California August 6th-9th

[57] Colesca, S. (2009), Understanding Trust in e-government. Engineering Decisions Journal, 3(3), 7-15

[58] Khasawneh, R. Rabayah, W. \& Abu-Shanab, E. (2013), E-government acceptance factors: trust and risk, Proceedings of The 6th International Conference on Information Technology (ICIT), Amman, Jordan, 8 May, 2013

[59] Suki, MN. \& Ramayah, T.( 2010), User acceptance of the e-government services in Malaysia: A structural equation modelling approach. Interdisciplinary Journal of Information, Knowledge and Management, 5, 395-413

[60] Vencatachellum, I. \& Pudaruth, S. (2010), Investigating e-government services uptake in Mauritius: A user's perspective, International Research Symposium in Service Management, Le Meridien Hotel, Mauritius, 24-27 August, http://www.uom.ac.mu/sites/irssm/papers/Vencatachellum\%20\&\%20Pudaruth\%20 \%2073.pdf

[61] Susanto, T, D and Goodwin, R. (2010) Factors Influencing Citizen Adoption of SMS-Based eGovernment Services, Electronic Journal of e-Government, 8(1), (55 - 71)

[62] Al-Ghaith, W. Sanzogni, L. \& Sandhu, K. (2010), Factors Influencing the Adoption and Usage of Online Services in Saudi Arabia. The Electronic Journal of Information System in Developing Countries, 40(1), 1-32

[63] Rahmath Safeena and Abdullah Kammani (2013), Conceptualization of electronic government adoption, International Journal of Managing Information Technology (IJMIT) 5(1), 13-22

[64] Sharma, S. K. (2007), Exploring Best Practices in Public-Private Partnership (PPP) in E- Government through Select Asian Case Studies. The International Information \& Library Review, 39 (3-4), 203210 .

\section{Authors}

Yousef Elsheikh is an assistant professor of Information Technology at the Applied Science University. He holds $\mathrm{PhD}$ in Informatics from University of Bradford, UK and MSc in Information Technology from University of the West of England, UK. He is currently working as a faculty staff member in Computer Science department at the Applied Science University. His research interests includes conceptual modeling, ebusiness applications, information systems engineering, knowledge based representations, Ontologies and issues in software engineering.

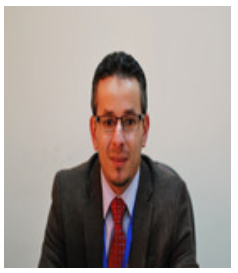

Mohammad Azzeh is an assistant professor of Software Engineering at Applied Science University. He holds PhD in computing from University of Bradford, UK and MSc in Software Engineering from University of the West of England, UK. He is currently working as a faculty staff member in software engineering department at Applied Science University. His research interests includes software cost estimation, software project management, Search-Based Software Engineering and applications of machine learning algorithms to Software Engineering problems such software management and testing.

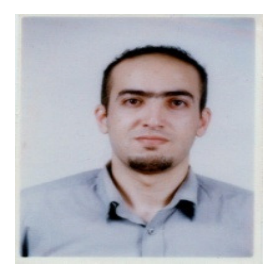

